\title{
TRUSTS OF THE FAMILY HOME: THE IMPACT OF OXLEY V HISCOCK
}

\author{
Dr Lorna Fox, Department of Law, University of Durham

\section{INTRODUCTION}

The regulation of ownership interests in the family home through the law of trusts has been the subject of considerable discussion for many years, much of which has focused on the inadequacies of trust law when it comes to dealing with the issues raised by family property disputes. ${ }^{1}$ Although the proportion of partners who expressly opt for joint ownership, or make express declarations of trust concerning the beneficial ownership of the family home, has increased exponentially in recent decades, a sufficiently significant number of cases remain in which ownership disputes subsequently emerge and must be resolved by the application of the principles of informal trusts (resulting trusts, constructive trusts, and proprietary estoppel) to attract the continuing attention of academic critics and law reformers. Critics typically focus on the over-dependence of resulting and constructive trusts on direct financial contributions, ${ }^{2}$ or on an express common intention between the partners. ${ }^{3}$ Various options for reform have been considered in England and Wales, ${ }^{4}$ Ireland, ${ }^{5}$ and Northern Ireland, ${ }^{6}$

1 There is a wealth of scholarly writing on the inadequacies of current trust law principles when determining interests in the family home, particularly since the decision in Lloyd's Bank Ltd v Rosset [1991]1 AC 107: see, for example, Gardner, 'Rethinking Family Property' [1993]109 LQR 263; see also Halliwell, M, 'Equity as Injustice: the Cohabitant's Case' (1990)20 Anglo-American Law Review 500; Mee, J, The Property Rights of Cohabitees (1999, Oxford: Hart Publishing); Barlow, A and Lind, C, 'A matter of trust: the allocation of rights in the family home' (1999)19 Legal Studies 468. The limitations of existing trust law principles for determining interests in the family home were acknowledged in the Law Commission's paper on the property rights of 'home-sharers': Sharing Homes (2002).

2 A requirement which is thought to penalise partners (often women) who either make indirect contributions to bills and other household expenses, or who make non-financial contributions through labour in the home and childcare; see Gardner, 'A woman's work. ..' [1991]54 MLR 126-129; cf Probert, 'Trusts and the modern woman - establishing an interest in the family home' [2001]13 Child and Family Law Quarterly 275.

3 Couples often fail to satisfy the express common intention requirement because they tend to deal with one another in an informal way, either because they don't 'turn their minds' to the prospect of a future dispute over their shared home, or because they do not believe that, in the context of their relationship, they have any need of legal protection, see below, n.18 and associated text.

4 In Sharing Homes: A Discussion Paper (2002), the Law Commission reported on its deliberations, but did not make recommendations; rather it set out a scheme that had been considered involving a statutory trust, which would have conferred beneficial ownership interests based on a wide range of contributions, for a broad category of homesharers. This followed the Law Commission's earlier proposals for the introduction of a system of statutory co-ownership between spouses: Family Property Law, Law Com WP No 42 (1971), First Report on Family Property: A New Approach, Law Com No 52 (1973), Third Report on Family Property: 
but none have resulted in legislation. In the absence of substantive legislation, efforts to address the deficiencies of the law in this area in England and Wales now appear to have been re-focused on reducing the number of cases where recourse is made to the law of trusts by extending the court's jurisdiction to re-distribute property between same-sex couples who have registered as civil partners, ${ }^{7}$ as well as a more general review of the law relating to cohabitation. ${ }^{8}$ However, while these initiatives would have the effect of reducing the volume of case law determined under the general law of trusts, a number of cases ${ }^{9}$ must still be resolved according to the 'default positions' ${ }^{10}$ of ordinary trust law, as was the case in the recent decision in Oxley v Hiscock. ${ }^{11}$

The decision in Oxley v Hiscock marks an interesting development of the case law pertaining to Trusts of the Family Home. The decision, which principally turned on the question of quantifying shares when a cohabiting partner has successfully established an interest under a common intention constructive trust, indicates once again the efforts of the Court of Appeal to bring greater fairness and flexibility to bear in this area of property law. In many respects, the decision of the Court of Appeal can be seen as part of a more general trend, following on the heels of the decision in Le Foe v Le Foe, ${ }^{12}$ and Sharing Homes. ${ }^{13}$ In Le Foe v Le Foe, the court adopted a more flexible approach regarding the types of contributions that may give rise to an implied common intention constructive trust. This was welcomed by the Law Commission in Sharing Homes, when it suggested that, alongside the development of wider legislative powers of distribution in the context of relationship breakdown between non-married (including same-sex) couples, the English courts should develop more flexible judicial principles to govern

Matrimonial Homes (Co-ownership and Occupation Rights) and Household Goods, Law Com No 86 (1978), Family Law: Matrimonial Property, Law Com No 175 (1988), and the intervening, but unsuccessful, Matrimonial Homes (Coownership) Bill 1980.

5 The Irish Law Reform Commission has recently issued a Consultation Paper on The Rights and Duties of Cohabitees (LRC CP 32-2004), which includes consideration of the difficulties associated with the application of trusts law in the area of family property.

6 In Northern Ireland, the Law Reform Advisory Committee (Northern Ireland) attempted to address the difficulties associated with trusts of the family home in its Consultation Paper (1999) and Final Report (2000) on Matrimonial Property, but again this did not result in legislation. See Fox, L, 'Co-ownership of Matrimonial Property: Radical Proposals for Reform' (2001)52 NILQ 20-53.

7 See Civil Partnerships Bill 2002 (HL Bill 41); Civil Partnership Bill 2004 (HL Bill 132).

8 See Law Society, Cohabitation: the case for clear law (2002, London: Law Society).

9 For example, where opposite-sex (or same-sex) partners either could marry (or register), but choose not to, or can't marry (or register) because either (or both) is still married to (or in a registered partnership with) another.

10 See Miles, J, 'Property law $\mathrm{v}$ family law: resolving the problems of family property' (2003)23 Legal Studies 624 at 626.

11 [2004] EWCA Civ 546.

12 [2001]All ER 325 (HC); [2001]EWCA Civ 1870 (CA).

13 Op. cit. 
the acquisition of interests in property under implied trusts. ${ }^{14}$ One of the themes of the Law Commission's paper was the difficulties inherent in striking a balance between certainty and fairness in the field of trusts of the family home. ${ }^{15}$ This issue was highlighted once again in Oxley v Hiscock: while judicial policy appeared, until recently, to be overwhelming dominated by the importance of achieving certainty in this area, ${ }^{16}$ the decision in Oxley $\mathrm{v}$ Hiscock provided further evidence of a growing judicial tendency to prioritise fairness when determining disputes involving trusts of the family home.

\section{The Facts of Oxley v Hiscock}

In Oxley v Hiscock the disputed property was 35 Dickens Close (the 'Dickens Close' property) and had been the shared home of Mr Hiscock and Mrs Oxley. The property was registered in Mr Hiscock's name, but had been purchased in 1991 for the purpose of housing Mr Hiscock, Mrs Oxley and her children from a former marriage. The parties lived together in the property from 1991 until their relationship ended in 2001, by which time the mortgage had been discharged and the property had been sold for $£ 232,000$. The Dickens Close property was not, however, their first shared home, and in order to unravel the parties' beneficial interests in that property, it was necessary to go back to the beginning of their cohabiting relationship. Since trusts of the family home are both triggered by, and quantified according to, the parties respective contributions to the property and their common intentions regarding beneficial ownership, the whole history of their property sharing relationship was reviewed by the court.

Mr Hiscock and Mrs Oxley met in 1985, when Mrs Oxley was a secure tenant of her house in Bean, Kent (the 'Bean property'). At that time, $\mathrm{Mr}$ Hiscock worked in Kuwait, but he stayed with Mrs Oxley in the Bean property whenever he was in the United Kingdom. In 1987, Mrs Oxley exercised her right to buy this property, valued at $£ 45,200$. The property was conveyed into Mrs Oxley's name, but she was not in a position to provide the whole purchase price. Rather, her right-to-buy discount of $£ 20,000$ reduced

14 "The possibility of judicial development of the law does however remain, and. . we shall discuss whether there are particular ways in which reform could be advanced by the courts. We shall first consider how the other leading common law jurisdictions - Australia, Canada and New Zealand - have dealt with the problem - and how their courts have applied and developed doctrines such as the constructive trust. . . for the most part these jurisdictions have adopted a somewhat more expansive approach to constructive trusts than that apparent in England and Wales. .. We shall however make suggestions for the continuing development of the common law by the English courts."; Sharing Homes, op. cit., para.4.3.

15 The Law Commission compared the strict approach adopted in the English courts with the more flexible systems that have developed in the Commonwealth jurisdictions, and suggested that: " $[\mathrm{t}]$ here is no doubt that the broader approach of these [Commonwealth] jurisdictions tends to lead to greater uncertainty and unpredictability than the current English law, but this may be a necessary consequence of fairness. . . the courts should seek to be more flexible in their approach." Sharing Homes, para.4.23.

16 The decision of the House of Lords in Lloyd's Bank Ltd v Rosset, op. cit., tended towards certainty rather than flexibility: see Gardner, op. cit., who described this as a 'bright-line' approach to the development of the law. 
the amount due to $£ 25,200$, and the balance was provided by Mr Hiscock by way of a loan to Mrs Oxley. Despite his contribution, rather than conveying the property into their joint names, the property was conveyed into her name alone in order to safeguard the right to buy discount, ${ }^{17}$ and Mr Hiscock's contribution was protected by way of a charge over the property. In 1991, the Bean property was sold for $£ 61,500$.

These facts provided the background to the dispute that came before the court concerning the Dickens Close property, which was purchased in 1991 for $£ 127,000$. The parties' respective contributions to the purchase price of the property is a crucial issue when it comes to determining whether a claimant has acquired an interest under a family home trust, and when calculating the extent of that interest. With regard to the Dickens Close property, both partners made some financial contribution - Mr Hiscock paid a total of $£ 60,700$ towards the deposit, $£ 25,200$ of which came from the sale of the Bean property, and Mrs Oxley paid $£ 36,300$, which represented her share of the Bean property. The balance of the purchase price $(£ 30,000)$ was provided by a mortgage, which the court presumed had been discharged in equal shares. Curiously, the Dickens Close property was registered in $\mathrm{Mr}$ Hiscock's sole name despite advice from their solicitor that the property should be in their joint names. Mrs Oxley directed the solicitor that the conveyance was to be to Mr Hiscock alone, adding that:

"Your comments on any claim I might have to 35 Dickens

Close have been noted, and I appreciate your concern.

However, I am quite satisfied with the present arrangements, and feel I know Mr Hiscock well enough not to need written legal protection in this matter." 18

After they separated in 2001, Mr Hiscock and Mrs Oxley decided to sell 35 Dickens Close, and buy two properties, one for each to live in. The Dickens Close property was sold for $£ 232,000$, of which $£ 41,200$ was paid to Mrs Oxley. In November 2002, Mrs Oxley sought an order under section 14 of the Trusts of Land and Appointment of Trustees Act 1996 for a declaration that the proceeds of the sale were held by Mr Hiscock on trust for the parties in equal shares.

\section{Putting the Case in Context}

Before proceeding to consider the reasoning and the outcome in Oxley v Hiscock, it is useful to consider briefly the trusts context in which family home disputes are addressed. Two questions must be considered: the criteria governing the acquisition of an interest in the property, and the extent of any such interest.

17 The tenancy was regulated by the Housing Act 1985, which required that a tenant who had purchased property under the right-to-buy provisions, but who subsequently disposed of that property within three years, could be required to repay part of the discount (s.155).

18 See Oxley v Hiscock, op. cit., para.9. 


\section{(a) Acquiring an interest in the family home: a whistle-stop tour}

Proprietary interests in the family home may be acquired under general property law either expressly or impliedly. Although statistics on the proportion of matrimonial homes which are expressly held by partners as joint legal or equitable owners are unavailable, it is generally accepted that the proportion of partners opting to become express joint legal owners of the matrimonial home has significantly increased in recent decades, particularly since the landmark and high profile case of Williams \& Glyn's Bank Ltd v Boland, ${ }^{19}$ which prompted Lord Scarman to suggest (extra-judicially) that:

“. . . we should encourage young married people to go round the corner to the solicitor, or, if we could establish one, the legal clinic, to talk about the legal problems of marriage just as they go to the medical clinic to discuss the medical problems associated with what is euphemistically called family planning. ${ }^{20}$

It is interesting to note, however, that although Mrs Oxley did receive legal advice recommending that the property was placed in their joint names, she declined to do so on the basis that she: ". . . fel[t] I know Mr Hiscock well enough not to need written legal protection in this matter." Her response is testament to the persistent need for recourse to the law of trusts in order to resolve family home disputes, even when the partners have received legal advice at the time of the conveyance.

Where there is no express agreement to share ownership, partners may attempt to establish an implied trust. Non-owning partners may acquire an equitable interest in the property under: an implied resulting trust, on the basis of financial contributions to the purchase price of the property; ${ }^{21}$ an implied constructive trust, which is based on either the common intention of the parties that beneficial ownership shall be shared (by agreement, arrangement or understanding) along with detriment suffered by the nonowning partner, or direct financial contributions to the purchase price of the property;22 or by proprietary estoppel, where the requirements of representation, reliance and detriment must be present. When an interest arises under one of these informal trusts, rather than by a joint conveyance or express declaration, the further issue of shares in the property must also be addressed.

[1981]AC 487

20437 HL Deb (5 ${ }^{\text {th }}$ Series) col.652 (15 December 1982) Lord Scarman.

21 When a partner acquires an interest under a resulting trust, the portion of the equitable estate acquired will be proportionate to the amount of the financial contributions.

22 See McFarlane v McFarlane [1972] NI 59; Lloyd's Bank plc v Rosset [1991] 1 AC 107. Although the decision in Le Foe v Le Foe [2001]2 FLR 970 suggested that the courts may be moving towards a more flexible approach regarding contributions - at least indirect financial contributions - to the acquisition of an interest in the matrimonial home under a constructive trust, this approach has not yet been endorsed by the Court of Appeal. 


\section{(b) Quantifying interests in the family home: the impact of Midland Bank plc v Cooke}

In the last ten years a significant distinction has emerged in the field of trusts of the family home, between the resulting trust and the constructive trust, in relation to the way in which the quantum of shares in the beneficial interest is calculated. The principles for quantifying the claimant's share under a resulting trust are straightforward: a direct contribution to the purchase price of property will give rise to a presumed resulting trust, normally in proportion to the amount of the contribution. On the other hand, the principles governing the quantification of interests under common intention constructive trusts have, in recent years, developed to become more flexible, more concerned with achieving a fair outcome, and, as a result, less predictable. An agreement, arrangement or understanding to share the beneficial interest AND detriment OR a (probably direct) ${ }^{23}$ financial contribution will give rise to a common intention constructive trust. However, in a number of cases involving common intention constructive trusts, the court has taken a more flexible approach towards quantum.

A landmark decision concerning the quantification of interests acquired under a common intention constructive trust was Midland Bank plc v Cooke ${ }^{24}$ when the Court of Appeal calculated the claimant's share in the family home by conducting a: ". . . survey of the whole course of dealing between the parties relevant to their ownership and occupation of the property and their sharing its burdens and advantages." 25 If that survey was inconclusive, then, and only then, the court could fall back on the maxim 'equality is equity'. Since Mr and Mrs Cooke were regarded as a couple who had shared everything - Mrs Cooke's contributions to their shared life included bringing up the children, working, at various stages, both part-time and full-time to pay household bills, and being a co-signatory to a second mortgage - her share was quantified at 50\%. The decision in Cooke highlighted the difference in outcome, depending on whether the claimant was awarded an interest under a resulting trust, by which reasoning Mrs Cooke would have acquired a $6.74 \%$ share, proportionate to her direct financial contribution, or under a common intention constructive trust, which enabled the court to apply a broad-brush approach to a whole range of conduct and contributions when considering quantum. However, as the decision of the Court of Appeal in Oxley v Hiscock has recently indicated, a number of further issues - both practical and doctrinal - remained outstanding with regard to the application of this 'broad-brush' approach. This article argues that although the decision in Oxley v Hiscock unpacked and, to a certain extent resolved some of these issues, some significant questions remain concerning the principles governing quantum when an interest is acquired under a common intention constructive trust.

23 Le Foe v Le Foe, op. cit

24 [1995]2 FLR 915.

25 ibid., at 926, per Waite LJ. 


\section{The Decision in Oxley v Hiscock}

\section{(a) The decision at first instance}

The case was heard, at first instance, in the County Court by Her Honour Judge Hallon. Firstly, it should be noted that the question of acquisition of an interest in property, and therefore the fact that Mrs Oxley was entitled to a share of the proceeds of sale, was not at issue. In fact, as noted above, she had already been paid $£ 41,200$ of the $£ 232,000$ raised by the sale of the Dickens Close property. Rather, the case turned on the quantification of her share. Mrs Oxley claimed that she was entitled to a half share in the property, and brought an action for a declaration to that effect under section 14 of the Trusts of Land and Appointment of Trustees Act 1996. In support of her claim, Mrs Oxley asserted several facts: that the parties had discussed marriage in 1988 but had not married due to financial disadvantages to $\mathrm{Mr}$ Hiscock; that they had pooled their resources as if they were a married couple; and that they had agreed to have 35 Dickens Close in Mr Hiscock's name alone in order to prevent any possible claim by Mrs Oxley's former husband, all the while having agreed between them that the beneficial ownership would be shared equally. Mr Hiscock refuted these assertions, and there was no independent evidence in support of any agreement having been made. Judge Hallon preferred the evidence of Mrs Oxley, and held that the (inferred) intention of the parties was that Mrs Oxley was to have a beneficial interest in the property.

On the issue of quantification, the judge held that, again, an intention could be inferred that the parties had agreed the proportions of their interests, based on their course of dealing. Following the authority of Midland Bank Ltd $\mathrm{v}$ Cooke, Judge Hallon began by looking for evidence of an express agreement between the parties as to their respective shares. Having found no evidence of an express agreement, she went on to apply the principles set out by the Court of Appeal in Midland Bank Ltd v Cooke, specifically the statement of Waite LJ that:

“. . . positive evidence that the parties neither discussed nor intended any agreement as to the proportions of their beneficial interest does not preclude the court, on general principles, from inferring one." 26

Judge Hallon inferred the agreement to share equally from the course of dealings between the parties, focusing particularly on their 'long term plan' to acquire a joint property, and the evidence that each of the parties had regarded both properties as 'their home'. Judge Hallon held that the course of dealing between Mr Hiscock and Mrs Oxley gave rise to an inference that they intended each to have an equal share in the property, and consequently ordered that the claimant was entitled to a half share of the proceeds of sale of the property. The defendant appealed against that order.

26 [1995]2 FLR 915 at 928, per Waite LJ. 


\section{(b) The decision of the Court of Appeal}

The judgment of the Court of Appeal was delivered by Chadwick LJ.27 Firstly, the Court of Appeal confirmed the inference of an intention that Mrs Oxley would have some beneficial interest in the property, since that was thought to be the only possible explanation of their discussion as to whose name should appear on the title in the context of a possible claim by her former husband. ${ }^{28}$ It is interesting that the court focused on this factor, since her claim was, in any event, clearly established by her direct financial contributions to the purchase, bringing the case within the second of Lord Bridge's categories in Lloyd's Bank plc $\mathrm{v}$ Rosset. ${ }^{29}$ This focus on their discussions did, however, provide an interesting signpost to the overall direction taken by the Court of Appeal. In addressing the preliminary 'threshold' question of whether Mrs Oxley had acquired any interest in the property, Chadwick LJ stated that the parties' discussion concerning the possibility of her former husband making a claim in the event of her death was: "... only explicable on the basis that they both intended - and expressed that intention to the other - that each should have a beneficial share in the property." 30 Further, this finding was described as: "[the] feature which, to my mind, provides the foundation for Mrs Oxley's claim in constructive trust or proprietary estoppel; and which distinguishes that claim from one founded on resulting trust alone." 31

On the second question - the principles governing the quantification of interests acquired under a common intention constructive trust - the Court of Appeal conducted a thorough review of the authorities before granting the appeal on the grounds that the court cannot infer an intention to share equally unless, by looking at subsequent dealings between the parties, one could conclude that their common intention at the time the property was acquired must have been that they should each have an equal share. Crucially, the court held that the inference of an intention to share equally was only permissible if that was the only conclusion consistent with their conduct. When an intention to share equally could not be so inferred, Chadwick LJ held that the correct approach, in the absence of an express agreement, was for the court to ask:

"What would be a fair share for each party having regard to the whole course of dealing between them in relation to the property?"

When the breakdown of contributions between Mrs Oxley and Mr Hiscock was analysed, the court found that Mr Hiscock had made a greater direct financial contribution to the acquisition of the property, of $£ 60,700$ to her $£ 36,300$. The balance of the purchase price had been paid by a mortgage, which the court regarded as having been discharged from pooled resources.

27 Mance and Scott Baker LJJ concurred.

28 Oxley v Hiscock, op. cit., para. 14.

29 [1991]1 AC 107.

30 Oxley v Hiscock, op. cit., para.14.

31 ibid. The relationships between these three methods for the informal acquisition of interests in the family home: resulting trust, common intention constructive trust, and proprietary estoppel; would be one of the key themes to emerge from the Court of Appeal's decision in this case, and is considered further below. 
Based on these figures, Mr Hiscock's contribution accounted for just over $62 \%$ of the purchase price. However, adopting the approach that shares should be determined according to what would be fair having regard to their whole course of dealing, the court held that Mrs Oxley's beneficial interest amounted to $40 \%$ of the proceeds of sale.

\section{The Reasoning in Oxley v Hiscock}

The basis of the appeal was Mr Hiscock's argument that the judge had misdirected herself in law by refusing to follow the (pre-Cooke) decision of the Court of Appeal in Springette v Defoe, ${ }^{32}$ that is, that:

"If two or more persons purchased property in their joint names and there was no declaration of trusts on which they were to hold the property, they held the property on a resulting trust for the persons who provided the purchase money in the proportions in which they provided it, unless there was sufficient specific evidence of their common intention that they should be entitled in other proportions, that common intention being a shared intention communicated between them and made manifest at the time of the transaction itself."

Counsel for $\mathrm{Mr}$ Hiscock argued that, notwithstanding any subjective intentions of the parties, there had been no discussion as to the extent of their respective beneficial interests at the time of purchase. Consequently, it was argued, the presumption of resulting trust had not been displaced, and the property was held for Mr Hiscock and Mrs Oxley in shares proportionate to their contributions.

In considering the appeal, Chadwick LJ conducted a very detailed exposition of the authorities in this area over the last twenty years, beginning with the decision in Walker v Hall, ${ }^{33}$ when the court held that in determining shares under the implied trusts, there were no special rules for cohabitants, that the (less flexible) resulting trust analysis should be applied, and that there was no justification for departing from proportionate shares in the absence of an express contrary intention. The court was not prepared to infer an intention that the partners would hold in equal shares just because the property was a family home, and neither was it considered appropriate to 'top up' the claimant's share on the grounds of fairness. The decision in Turton $\mathrm{v}$ Turton $^{34}$ testified to a similarly restrictive approach, when the court held that the quantification of shares must be divined from the intentions of the parties at the time of the purchase, and could not be left for determination in the light of subsequent events. On the other hand, in the intervening decision in Grant v Edwards ${ }^{35}$ the court appeared to adopt a wholly different approach by recognising the particular issues raised by implied trusts cases between cohabitants, and adopting a more flexible analysis of the 'quantum question' accordingly.

\footnotetext{
[1992]2 FLR 388.

[1984]FLR 126.

34 [1988]Ch 542.

35 [1986]Ch 638.
} 
In Grant v Edwards, ${ }^{36}$ the court showed greater awareness of the reality of the family home context, by focusing on the difficulties presented when a claimant has made contributions that are substantial but difficult to identify or to quantify. Lord Browne-Wilkinson V-C drew on the law of proprietary estoppel in relation to the quantum question, and held that the court should give effect to the parties' common intention so far as this may be achieved with fairness between the parties. This introduced a new note of flexibility to the law of implied trusts, as the court held that while identifiable financial contributions were one of the factors to be taken into account, labour contributions and other unquantifiable actions could also be relevant. A few years later, in Stokes v Anderson, ${ }^{37}$ the similarities between the common intention constructive trust and proprietary estoppel were highlighted once again, in order to justify adopting a more flexible approach to the constructive trust at the quantum stage. The court's concern with achieving a fair outcome was a central feature of these decisions, and this also necessitated a shift of focus, from the parties' intentions when purchasing the property, to consider instead the position between them and in respect of the property after the mortgage had been paid, or when the property was being disposed of.

The decisions in Springette v Defoe $e^{38}$ and Huntingford $\mathrm{v} H o b b s,{ }^{39}$ on which the appellant based his argument, appeared to indicate a return to the more rigid approach of Walker $\mathrm{v}$ Hall ${ }^{40}$ and Turton $\mathrm{v}$ Turton. ${ }^{41}$ In both cases, the Court of Appeal attempted to re-establish the proposition that there should be no difference in the approach taken when applying the principles of resulting and constructive trusts to cohabitants in family homes. Rather, the earlier principles were re-asserted: that the court must begin by considering whether there was any evidence of an express common intention concerning quantum. Only in default of such evidence would shares then be determined in proportion to direct financial contributions. In swinging the pendulum back towards certainty rather than flexibility, this approach also aligned the common intention constructive trust more closely with the presumed resulting trust, rather than the principles of proprietary estoppel. ${ }^{42}$

36 The judgment drew on the decision in Gissing v Gissing [1971]AC 866, when the House of Lords held that, where no agreement was reached between the parties as to their respective shares in the family home: “. . . the court must first do its best to discover from the conduct of the spouses whether any inference can reasonably be drawn as to the probable common understanding about the amount of the share of the contributing spouse upon which each must have acted in doing what each did, even though that understanding was never expressly stated by one spouse to the other or even consciously formulated in words by either of them independently."

37 [1991]1 FLR 391.

38 (1992)24 HLR 552.

39 [1993] 1 FCR 45. Both decisions were handed down on the same day by the same Court of Appeal panel of Dillon, Steyn and Slade LJJ.

40 Op. cit.

41 Op. cit.

42 The status of these authorities was, however, queried in Oxley v Hiscock, when Chadwick LJ cast doubt on whether the position adopted in Springette v Defoe and Huntingford $\mathrm{v}$ Hobbs accurately reflected the state of the law by that time, para.60. 
A final strand of reasoning identified from the case law was based on the decision in Midland Bank Ltd $\mathrm{v}$ Cooke, ${ }^{43}$ when Waite LJ, explicitly addressing the dilemma of the conflicting case law, considered whether to infer an agreement that the parties intended to share ownership equally, or to recognise Mrs Cooke's beneficial interest in proportion to her direct financial contributions. The court's solution in this case was to undertake a survey of the whole course of dealing between the parties, taking into consideration all conduct which cast light on the question of what shares were intended. Only if that proved inconclusive, was the court to fall back on the maxim 'equality is equity'. This third strand of reasoning, like the decisions in Grant v Edwards and Stokes v Anderson, acknowledged the particular circumstances that give rise to problems when the disputed property has been a family home. Waite LJ noted that it is typical of cohabitation relationships that the partners do not fully articulate agreements concerning their shares to the family home, and suggested that:

"It would be anomalous, against that background, to create a range of home-buyers who were beyond the pale of equity's assistance in formulating a fair presumed basis for the sharing of beneficial title, simply because they had been honest enough to admit they never gave ownership a thought or reached any agreement about it." 44

Consequently, under the Cooke approach, it was held that even if parties expressly stated that they had reached no agreement, this would not prevent the court from inferring an agreement as to quantum on general equitable principles. ${ }^{45}$

These three distinct strands of authority emphasise one of the difficulties identified by Gibson LJ in Drake v Whipp, that: “. . . as is notorious, it is not easy to reconcile every judicial utterance in this well-travelled area of the law."46 Nevertheless, in Oxley v Hiscock, Chadwick LJ attempted to rationalise the case law and, in the process, adopted a firm policy stance on a number of the issues underpinning the diverse authorities. Firstly, concerning the question of applying specific principles where the disputed property is a family home, Chadwick LJ followed the decisions in Grant v Edwards and Stokes v Anderson in recognising the particular context of relationships between cohabitants. The 'cases of this nature', to which the principles identified in his judgment applied, were those in which: the property is bought as a home for a couple who, although not married, intend to live together as man and wife; each of them makes some financial contribution to the purchase; the property is purchased in the sole name of one of them; and there is no express declaration of trust. Consequently, and again echoing the Grant v Edwards line of authority, it was held that in such cases, when there is no express evidence of an agreement as to shares: “. . .

43 [1995]2 FLR 915.

44 ibid., at 927, per Waite LJ.

45 This was the approach adopted by Judge Hallon in the County Court in Oxley v Hiscock, supra.

46 [1996]1 FLR 826 at 827. 
the court must supply the common intention by reference to that which all the material circumstances have shown to be fair." 47

In applying this test, Chadwick LJ suggested that the first, or threshold, question to be considered was whether there was evidence from which to infer a common intention, which had been communicated between the parties. Whether the constructive trust was based on an 'agreement, arrangement or understanding', or inferred on the basis of direct financial contributions, the quantum issue would in many cases be resolved by evidence relating what the partners had said and done at the time of the acquisition. However, when there was no evidence of any discussion between them as to the extent of the share which each was to have - or when the evidence was that there was no discussion on that point - the issue of quantum must still be resolved. In such cases, the Court of Appeal held that:

". . . each is entitled to that share which the court considers fair having regard to the whole course of dealing between them in relation to the property. And, in that context, 'the whole course of dealing between them in relation to the property' includes the arrangements which they make from time to time in order to meet the outgoings (for example, mortgage contributions, council tax and utilities, repairs, insurance and housekeeping) which have to be met if they are to live in the property as their home." 48

Chadwick LJ identified three ways of reasoning towards the conclusion that the court could quantify interests according to what was considered fair in light of all the evidence: firstly, that the court could impute an agreement that the shares should be determined according to what was considered fair at the end of the relationship; ${ }^{49}$ that the court could make an assessment of what the parties must have intended from the outset, looking at the whole course of dealing between the parties; ${ }^{50}$ or that the court could award such an interest as seems to be fair on a proprietary estoppel basis. ${ }^{51}$

Here, again, Chadwick LJ adopted a clear and principled approach to the various alternatives before the court which cut through the quagmire of conflicting case law. The judge admitted that he was disinclined to impute intentions to the parties regarding shares, or to imagine what the parties must have intended at the outset based on their subsequent course of dealing, since he considered it:

47 Stokes v Anderson, supra, at 399, per Nourse LJ; quoted by Chadwick LJ in Oxley v Hiscock, para 65; Chadwick LJ claimed that this position was also: “. . . what Lord Justice Waite had in mind when he referred, in Midland Bank v Cooke [1995]2 FLR 915, 927G, to 'equity's assistance in formulating a fair basis for the sharing of the beneficial title' in a case where the parties 'had been honest enough to admit they never gave ownership a thought'." (para.65)

48 Oxley v Hiscock, op. cit., para 69, per Chadwick LJ.

49 Based on Gissing v Gissing, op. cit., per Lord Diplock; Stokes v Anderson, op. cit., per Nourse LJ; see Oxley v Hiscock, op. cit., para.70.

50 Based on Midland Bank v Cooke, op. cit., per Waite LJ.

51 Based on Grant v Edwards, op. cit., per Sir Nicolas Browne-Wilkinson V-C; Yaxley v Gotts, op. cit., per Walker LJ; according to Chadwick LJ, this was also the principle underlying the decision in Drake v Whipp, op. cit. 
“. . . artificial - and an unnecessary fiction - to attribute to the parties a common intention that the extent of their respective beneficial interests in the property should be fixed as from the time of the acquisition, in circumstances in which all the evidence points to the conclusion that, at the time of the acquisition, they had given no thought to the matter." 52

Chadwick LJ concluded, therefore, that the third justification: that the court should award such an interest as seems to be fair on a proprietary estoppel basis; was the most satisfactory alternative, adding that: "I think that the time has come to accept that there is no difference in outcome, in cases of this nature, whether the true analysis lies in constructive trust or in proprietary estoppel." 53

Applying these principles to the case in hand, the Court of Appeal held, in relation to the first stage of the inquiry, there was insufficient evidence to establish that the parties had formed an intention as to shares. ${ }^{54}$ The court conceded that, if an intention as to shares had been found as a matter of fact, the court would not go behind those facts to impose a fair division of shares. In this case, however, there was no basis for such a finding of fact, and so the inquiry moved to the second stage. Since a common intention as to shares had not been established, the pursuit of 'intention' was no longer appropriate, but, rather, the question for the court was 'what would be a fair share for each party having regard to the whole course of dealing between them in relation to the property?' In applying this principle, Chadwick LJ overruled Judge Hallon's decision to grant an order declaring that the parties owned the beneficial interest in equal shares, on the grounds that it gave insufficient weight to Mr Hiscock's larger direct contribution to the purchase price. Rather, the Court of Appeal held that a fair share for each party in all the circumstances would be $60 \%$ to Mr Hiscock, and $40 \%$ to Mrs Oxley.

\section{The Implications of Oxley v Hiscock: Some Important Distinctions...or are they?}

A major practical impact of the decision in Oxley v Hiscock was the step-bystep guidance provided by the Court of Appeal for dealing with quantification of shares under common intention constructive trusts. Where there is no evidence of intentions as to shares, the court can determine what a fair share would be for each party, 'having regard to the whole course of dealing between them in relation to the property'. Furthermore, as Chadwick LJ acknowledged in his judgment, this approach also has implications on the distinctions between the various species of informal trusts under which interests in the family home may be acquired. Since Lord Diplock's remark, in Gissing v Gissing, ${ }^{55}$ that the informal acquisition of interests in the family home took place under: "A resulting, implied or constructive trust - and it is unnecessary for present purposes to distinguish between these three classes

52 Oxley v Hiscock, op. cit., para.71.

53 ibid.

54 Mr Hiscock's charge over the Bean property was held to be inconsistent with an intention to hold the property jointly and equally.

55 [1971]AC 886. 
of trust. . .",56 there has been considerable 'muddying of the waters' concerning the relationships between the presumed resulting trust, the common intention constructive trust, and proprietary estoppel, ${ }^{57}$ in respect of informal interests in the family home. The decision in Oxley v Hiscock casts a new light on the boundaries between these categories. While some distinctions have been reinforced - between the presumed resulting trust and the common intention constructive trust - others, such as that between the common intention constructive trust and proprietary estoppel, appear to have been blurred to the point of indecipherability.

\section{(a) Express common intention constructive trust and implied common intention constructive trust}

One of the distinctions highlighted in Oxley v Hiscock was between the two genus of common intention constructive trust: that based on express common intention, where the parties have reached an 'agreement, arrangement or understanding' that beneficial ownership will be shared, ${ }^{58}$ and the constructive trust based on implied common intention, evidenced by a direct financial contribution to the purchase price. ${ }^{59}$ In Oxley v Hiscock, the distinction was raised by counsel for Mr Hiscock, who argued that: (a) when an express common intention constructive trust is established, the parties must have expressed intentions in respect of both the 'threshold' question that they wished to share the beneficial ownership - and also as to the extent of their shares; and (b) that where an implied common intention constructive trust arose, the direct contributions both justified the inference of a common intention and defined (proportionately) the extent of the shares. If the Court of Appeal had accepted this argument, this would have left no scope for the court to adjust the shares, in either category, on grounds of fairness. Chadwick LJ disagreed with this argument, and held that the court was entitled to adjust the parties' respective shares in the interests of fairness, whether the constructive trust was based on express common intention or implied common intention. Where an express common intention constructive trust was established, it was necessary to show some agreement, arrangement or understanding, but not necessary that the agreement, arrangement or understanding extended to defining the extent of the respective shares. When a claimant relied on an implied common intention, common intention would be readily inferred from direct financial contributions. The relevant common intention, however, must merely be that each party should have some beneficial interest, but not necessarily in proportion to the amount of their direct contribution. ${ }^{60}$ Thus the two questions before the court: the 'threshold' question - of whether an interest has arisen under a constructive trust; and the quantum question - as to the respective shares of the parties; remained distinct. However, as the decision

56 ibid at 905.

57 See Hayton, D, 'Equitable Rights of Cohabitees' (1990) Conv 370; Ferguson, P, 'Constructive Trusts - A Note of Caution' (1993)109 LQR 114; Hayton, D, 'Constructive Trusts of Homes - A Bold Approach' (1993)109 LQR 485.

58 See for example, Eves v Eves [1975]1 WLR 1338; Grant v Edwards [1986] Ch 638; and more recently, Cox v Jones [2004]EWHC 1486

59 Lloyd's Bank plc v Rosset, op. cit.; see, however, Le Foe v Le Foe, op. cit., nn.2223 and associated text.

60 Oxley v Hiscock, op. cit., para.40. 
in Cox $\mathrm{v}$ Jones $^{61}$ has since confirmed, the quantum question is governed by the same set of principles whether the common intention constructive trust is based on express or implied common intention.

\section{(b) Resulting trust or constructive trust?}

If, as counsel for Mr Hiscock argued in Oxley v Hiscock, the court had no scope to adjust shares on an implied common intention trust, but was required to define the parties' interests in exact proportion to their direct financial contributions, then there would be little to distinguish the implied common intention constructive trust from a presumed resulting trust. However, although the facts giving rise to a resulting trust or a constructive trust in the family home may overlap, ${ }^{62}$ recent case law has tended to emphasise the distinctions between the categories of implied trust. In Drake v Whipp ${ }^{63}$ Gibson LJ stated that:

"[a] potent source of confusion, to my mind, has been suggestions that it matters not whether the terminology used is that of the constructive trust, to which the intention, actual or imputed, of the parties is crucial, or that of the resulting trust which operates on a presumed intention of the contributing party in the absence of rebutting evidence of actual intention." $" 64$

Although both are triggered by a direct contribution from the claimant to the purchase price of the property, the doctrinal distinctions were highlighted when the court came to quantify the claimant's share, since while a claim under a presumed resulting trust was calculated according to the 'strict proportions' rule, the Court of Appeal followed Grant $\mathrm{v}$ Edwards ${ }^{65}$ to hold that that the beneficial interest under a constructive trust was not held in shares proportionate to actual contributions, but calculated according to a more flexible formula, taking account of indirect financial contributions and non-financial contributions in an effort to achieve a fair result.

Although the decision in Carlton v Goodman ${ }^{66}$ added to the confusion once again by using the label 'resulting trust' to describe the outcome in Midland Bank $\mathrm{v}$ Cooke, ${ }^{67}$ the distinction was re-emphasised in McKenzie $\mathrm{v}$

61 Op. cit.

62 As was the case in Drake v Whipp [1996]1 FLR 826 when the Court of Appeal substituted a finding of implied common intention constructive trust based on direct financial contributions for the lower court's finding of presumed resulting trust based on contributions to the purchase price.

63 Op. cit.

64 ibid at 827, per Gibson LJ.

65 Op. cit.

66 [2002] EWCA Civ 545.

67 Op.cit. Ward LJ acknowledged the doctrinal issues surrounding the distinction, and suggested that: "[ $\mathrm{t}]$ he source of confusion between the constructive trust and the resulting trust. . . may be as potent as ever in view of Lord BrowneWilkinson's suggestion in Westdeutsche Landesbank Girozentrale v Islington $\angle B C$. . . that: 'Both types of resulting trust are traditionally regarded as examples of trusts giving effect to the common intention of the parties."'; (Carlton v Goodman, op. cit., para.33) he concluded that: "[w]e have not heard sufficient argument to become embroiled in, still less to resolve this confusion." (para.35). 
McKenzie. ${ }^{68}$ Robert Hildyard QC, sitting as Deputy Judge in the High Court, stated that:

"[b]oth [resulting and constructive trusts] constitute responses of equity where the parties have failed properly to document their intentions and no express provision has been made. In both cases the Court's decision whether such a trust has arisen involves an examination of the parties' intentions, based on statements, on conversations and on payments they have made. However, they are doctrinally distinct." 69

While the resulting trust has its basis in the presumption that a person is unlikely to have paid for property without expecting some return by way of a beneficial interest in that property, the common intention constructive trust has its roots in the common intentions of both parties. ${ }^{70}$ Judge Hildyard extended the doctrinal distinctions between the foundations of each category of trust to the principles governing quantification of shares, so that under a presumed resulting trust, the claimant's share would be 'commensurate to the value of the contribution which he or she had made and which has given rise to the presumption', ${ }^{71}$ while constructive trusts should be quantified according to the parties' common intention. The judge acknowledged that: "[t]he difficulty arises when though their common intention to share the property beneficially is clear or can be inferred, it is not possible to ascertain what their respective shares were intended to be."; ${ }^{72}$ but noted that although contribution may be relevant, in some cases the court has adopted a broader test of "what is fair and just in all the circumstances'. ${ }^{73}$

Nevertheless, the court in McKenzie v McKenzie was reluctant to accept that the principles advanced by the Court of Appeal in Midland Bank v Cooke C4 $^{74}$ went further, in terms of principle, than extending the range of factors from which the parties' common intention could be discerned beyond direct financial contributions. ${ }^{75}$ The decision in Oxley v Hiscock firmly reestablished the boundary between the resulting trust and the constructive trust in the family home context. Since the quantum principles governing common intention constructive trusts, as set out by the Court of Appeal, decisively shifted the focus of inquiry towards a more general 'fairness' approach, the implications of the doctrinal distinction between the resulting

Nevertheless, the judge also suggested that: "Midland Bank v Cook[e]. . . itself can only be properly understood when it is appreciated that the court was satisfied that by the making of a direct contribution a resulting trust had been established in the wife's favour of some part of the beneficial interest and the real question for the court in that case was to determine what proportions the parties must have been assumed to have intended for their beneficial ownership."; para.32.

68 [2003]EWHC 601

69 ibid., para.68.

70 ibid., para.76.

71 ibid., para.89.

72 ibid., para. 90.

73 ibid.

74 Op. cit.

75 McKenzie v McKenzie, op. cit., para.91. Judge Hildyard stated that: "I doubt that the Court of Appeal truly intended that quantification should be on any more arbitrary a basis.”; ibid. 
trust and constructive trust have been re-emphasised. Rather than treating the common intention constructive trust as a variant of the resulting trust, the court clearly distinguished the principles determining quantum in accordance with the underlying doctrinal basis of each type of trust.

\section{(c) Constructive trust or proprietary estoppel?}

While the distinctions between the resulting trust and constructive trust in relation to the acquisition of interests in the family home have been reenforced, the common intention constructive trust has been re-positioned in alignment with the doctrine of proprietary estoppel. ${ }^{76}$ Chadwick LJ's comment in Oxley v Hiscock, that: ". . . the time has come to accept that there is no difference in outcome, in cases of this nature, whether the true analysis lies in constructive trust or in proprietary estoppel."; ${ }^{77}$ sounded a clear note of conclusion in a long line of recent case law in which the distinctions between the common intention constructive trust and proprietary estoppel have been progressively eroded. ${ }^{78}$ Judicial statements allying the doctrines first began to emerge in the late 1980s, when Lord BrowneWilkinson, V-C, suggested that the principles underlying the law of proprietary estoppel might provide useful guidance both in regard to the conduct necessary to constitute acting on common intention (that is, detriment) so as to give rise to a constructive trust, and in regard to the quantification of the successful claimant's beneficial interest in the property. ${ }^{79}$ In Austin v Keele ${ }^{80}$ Lord Oliver, sitting on the Privy Council, described the doctrine of common intention constructive trust as 'an application of proprietary estoppel', while judgments of both the Court of Appeal and the House of Lords in the landmark case of Lloyd's Bank plc v Rosset $^{81}$ further indicated judicial sympathy with the idea that the doctrines were inter-related. ${ }^{82}$ In Lloyd's Bank plc v Carrick, ${ }^{83}$ Morritt LJ stated that: ". . . it is a matter of some doubt whether the principles of proprietary estoppel differ from those of that species of constructive trust which was referred to by Lord Bridge of Harwich in Lloyd's Bank plc v Rosset."; while in Yaxley v Gotts, ${ }^{84}$ Walker LJ suggested that although: "[p]lainly there are large areas where the two concepts do not overlap. . . But in the area of a joint enterprise for the acquisition of land (which may be, but is not necessarily, the matrimonial home) the two concepts coincide." $"$,

76 Notwithstanding Ferguson's (1993) observation that: "[c]onceptually the constructive trust is closer to the resulting trust than to proprietary estoppel. Both constructive and resulting trusts are mechanisms whereby the conduct of the parties leads by operation of law to the creation of a proprietary interest. . . Estoppel is conceptually different."; op. cit., 124.

77 Oxley v Hiscock, op. cit., para.71.

78 See, for example, Yaxley v Gotts [1999]3 WLR 1217; Chan Pui Chun v Leung Kam Ho [2002]EWCA Civ 1075; Jennings v Rice [2002]EWCA Civ 159.

79 Grant $\mathrm{v}$ Edwards, op. cit.

80 [1987]ALJR 605.

81 [1989]1 Ch 350; [1991]1 AC 107.

82 On five occasions in his judgment in Rosset, Lord Bridge referred to a 'constructive trust or proprietary estoppel'.

83 [1996]4 All ER 630.

84 [1999]3 WLR 1217.

85 ibid., at 1227. 
These statements are justifiable, and in all likelihood were motivated, by the fact that although constructive trusts and proprietary estoppel have different origins and histories, both depend on equity's treatment of claimants who have relied on an informal understanding that they were entitled to property legally held by another. ${ }^{86}$ In Oxley v Hiscock, the Court of Appeal emphasised the common features of the common intention constructive trust and the doctrine of proprietary estoppel, as earlier identified in Grant v Edwards: ${ }^{87}$ both are triggered by a claimant who, to the knowledge of the legal owner, acted in the belief that he or she had, or would obtain, an interest in land; both involve detrimental reliance on that belief, in both cases, equity acts on the conscience of the legal owner to prevent unconscionable actions. In short, that although: "[ $t]$ he two principles have been developed separately without cross-fertilization between them...they rest on the same foundations. .." 88

The decision of the Court of Appeal in Oxley v Hiscock, that the principles governing quantification of interests under common intention constructive trusts should, in the absence of evidence of a common intention as to shares, be determined according to what the court considered 'fair', shifted the common intention constructive trust closer yet to the doctrine of proprietary estoppel. Chadwick LJ concluded that: "[o]nce it is recognised that [this is] what the court is doing, in cases of this nature. . . it seems to me very difficult to avoid the conclusion that an analysis in terms of proprietary estoppel will, necessarily, lead to the same result. . ." 89 It is interesting to note that Chadwick LJ's decision was characterised by his concern to accurately reflect the court's process in the delineation of principles in this area, and to avoid the use of 'legal fictions'. ${ }^{90}$ This matter-of-fact approach suggests an attempt to encourage greater pragmatism in family home trusts, an area that has long been characterised by doctrinal confusion and lack of coherence, ${ }^{91}$ not least in relation to the quantification of interests, where the principles have been described as: “. . . uncertain, with decisions being made which are (not entirely surprisingly) inconsistent and difficult to reconcile." ${ }^{92}$

Nevertheless, and notwithstanding Chadwick LJ's statement that: “. . . it may be more satisfactory to accept that there is no difference, in cases of this nature, between constructive trust and proprietary estoppel."; ${ }^{93}$ the merging of the doctrine has not been universally accepted. In Sharing Homes, ${ }^{94}$ the Law Commission considered the case for assimilation before concluding

86 Caroline Sawyer has suggested that this area can be regarded as 'tiresomely confused rather than interesting'; see Walker J in Yaxley v Gotts [2000]Ch 162 at 176; Birmingham Midshires Mortgage Services Ltd v Sabherwal (2000)870 P\&CR 256 at 263; Sawyer, C, 'Equity's Children - Constructive Trusts for the New Generation' (2004)16 Child and Family Law Quarterly 31, at n.13.

87 [1986]Ch 638 .

88 ibid., at 656.

89 Oxley v Hiscock, op. cit., para.66.

90 See above, n.52 and associated text.

91 See, for example, see Glover \& Todd, 'The Myth of Common Intention' (1996)16 Legal Studies 325; Gardner, 'Rethinking Family Property' (1993)109 LQR 263.

92 Law Com, Sharing Homes: A Discussion Paper (2002), para. 2.109.

93 Oxley v Hiscock, op. cit., para.66.

94 Op. cit., paras.2.101-2.104. 
that: “. . . the extent to which proprietary estoppel and the common intention constructive trust overlap remains a difficult issue." ${ }^{95}$ In Hyett v Stanley, ${ }^{96}$ the Court of Appeal held that the doctrines had not yet been assimilated, while, in Lalani $\mathrm{v}$ Crump Holdings,${ }^{97}$ the court held that the doctrines remained distinguishable on the basis of the evidential standards applied: the standard of proof for a constructive trust was considered to be higher than that for proprietary estoppel. ${ }^{98}$

It is interesting to note that when English courts have favoured the idea of merging common intention constructive trusts with proprietary estoppel, it has tended to be on practical rather than doctrinal grounds: “. . . to solve the problems presented by these cases. . ."; 99 particularly in relation to quantification, in order to: “. . . produce a just result." ${ }^{100}$ In Stokes v Anderson, ${ }^{101}$ Nourse LJ argued that: “. . . there is no real reason for thinking that their assimilation would be unduly hindered by their separate development out of basically different factual situations." 102 Nevertheless, in Oxley v Hiscock, in common with the other cases in which the case for assimilating the doctrines was advanced, the theoretical distinctions between the constructive trust and the proprietary estoppel were not considered, nor did the judgment address the potential implications of assimilation. Furthermore, although some of the theoretical distinctions can be attributed to their separate origins, the development of each doctrine, from those origins, along different paths remains significant. For example, while the constructive trust is focused on enforcing common intention, proprietary estoppel is focused on avoiding detriment. Also, and significantly for practical purposes, the common intention constructive trust arises by operation of law in circumstances of unconscionability: once the criteria have been satisfied, the trust arises automatically. ${ }^{103}$ On the other hand, proprietary estoppel arises to enable a claimant who has suffered detriment following reliance on a representation by the defendant to seek a remedy. ${ }^{104}$ While the constructive trust is 'institutional', so that the court recognises a property right that has arisen automatically, estoppel is remedial, and so operates at the discretion of the court. ${ }^{105}$

These distinctions are crucial when it comes to considering the interests of third parties in family property. The constructive trust gives rise to an automatic beneficial interest once the elements of the trust are in place, so that the claimant's rights may predate, and so may take priority over, claims on the property by third parties. In contrast, when a proprietary estoppel is established, the claimant acquires no more than an inchoate equity until the

95 ibid, para.2.110.

96 [2003]EWCA Civ 942.

97 [2004]All ER (D) 181.

98 This proposition was earlier raised by Ferguson, op. cit. at 117.

99 Stokes v Anderson, op. cit., at 399.

100 ibid.

101 Op. cit.

102 Stokes v Anderson, op. cit. at 399.

103 In Re Sharpe (A Bankrupt) [1980]1 WLR 219.

104 Westdeutsche Landesbank Girozentrale v Islington LBC [1996]2 All ER 961.

105 For an illustration of the breadth of that discretion, see Pascoe v Turner [1979]2 All ER 945. 
court makes an award: consequently, with proprietary estoppel the remedy can be tailored to fit the wrong, and third parties will not be affected unless their conscience is affected by the estoppel claim. ${ }^{106}$ While the facts of Oxley $\mathrm{v}$ Hiscock did not involve any third party interest, the assimilation of the common intention constructive trust with the doctrine of proprietary estoppel would raise significant issues where the claimant's interest vied for priority with that of a creditor or a trustee in bankruptcy. In such a case, it would be necessary for the court to consider more fully the implications of: ". . . accept[ing] that there is no difference, in cases of this nature, between constructive trust and proprietary estoppel."107 Whilst the commonalities between the criteria for establishing an interest under each doctrine can be advanced to justify the assimilation of the principles by which interests arising are quantified, the nature of the interest arising under the constructive trust as compared with an estoppel are not the same. ${ }^{108}$ Consequently, it is suggested that although the courts will welcome greater scope for flexibility and fairness in determining quantum under a common intention constructive trust, further matters, particularly concerning the stage at which the interest arises, and its standing vis-à-vis third parties, must yet be resolved before it is legitimate to conclude that 'there is no difference' between the constructive trust and proprietary estoppel.

\section{CONCLUSIONS}

The decision in Oxley v Hiscock can be welcomed on a number of grounds. Firstly, the Court of Appeal has brought a greater degree of clarity to an area of law that has been dogged by confusion, inflexibility and stalemate. ${ }^{109}$ One of the persistent tensions in this area has been between the goals of certainty and flexibility. Since the landmark decision in Lloyd's Bank Ltd v Rosset, ${ }^{110}$ which set strict criteria for the acquisition of interests in the family home under constructive trusts, the tendency of the English courts has been to veer towards certainty, and this was apparently endorsed in the English Law Commission's paper Sharing Homes, ${ }^{111}$ when it suggested that any development of judicial principles should be directed at achieving: “. . . greater clarity, greater fairness, and greater certainty." 112 In a subsequent chapter, the Commission went on to argue, however, that the development of implied trusts in England should follow the direction of the Commonwealth

106 See for example, Binions v Evans [1972] Ch 359.

107 Oxley v Hiscock, op. cit., para. 66, per Chadwick LJ.

108 These issues were raised by Ferguson, op. cit., in her 1990 response to Hayton's argument in favour of the assimilation of constructive trusts and proprietary estoppel. Although Hayton argued that the development of a remedial constructive trust would obviate these difficulties, this has not yet occurred in English law: Westdeutsche Landesbank Girozentrale v Islington LBC, op. cit., at 997, per Lord Browne-Wilkinson.

109 One need look no further than the English Law Commission's Home Sharers project, which concluded after nine years of inquiry that, although it recognised the flaws of the existing law, it had not managed to formulate proposals for reform or even consultation.

110 Op. cit.

111 Sharing Homes, op. cit.

112 ibid., para.2.114. 
jurisdictions. ${ }^{113}$ Although the Law Commission conceded that: “. . . [t]here is no doubt that the broader approach of these jurisdictions tends to lead to greater uncertainty and unpredictability than the current English law. .."114 it was suggested that: ". . . this may be a necessary consequence of fairness."115 The focus on fairness in Oxley v Hiscock obviously enhances the flexibility of the law governing common intention constructive trusts, at least so far as the quantum of interests is concerned. This followed on the heels of the decision in Le Foe v Le Foe, ${ }^{116}$ which purported to widen the criteria for the acquisition of an interest under an implied common intention constructive trust when Mostyn J, reading Lord Bridge's speech in Rosset, suggested that his Lordship: ". . . does not state the proposition he advances in absolute terms."; 117 but read a degree of flexibility into the criteria set out by Lord Bridge. 118

The difficulties encountered by law reformers in this area ${ }^{119}$ highlight the challenges associated with adopting a single system of property rights in relation to home sharers that can be said to: “. . . operate fairly and evenly across the diversity of domestic circumstances which are now to be encountered." 20 It has become increasingly clear that the courts, also, would welcome a greater degree of flexibility, enabling them to respond accordingly to the diverse facts and circumstances presented by contemporary family property disputes. Family home cases no longer follow a standard pattern of husband and wife (or even cohabitants) where the male provider - and property owner - works and pays the mortgage, while the female homemaker - the claimant - takes care of children and labours in the home. Modern litigation concerning trusts of the family home reflects contemporary social and family life, including diverse divisions of labour and responsibility for financial and non-financial matters, ${ }^{121}$ and, significantly, a broad spectrum of claimants with varying awareness of the need to safeguard their interests within property sharing relationships. The courts are still faced with 'hard cases' - in Le Foe v Le Foe, the claimant had been married to Mr Le Foe for forty years, during which time he had made several fraudulent misrepresentations in order to re-mortgage the home without her consent, while hiving off funds to purchase another property for

113 The report reviewed the law in Canada, Australia and New Zealand.

114 Sharing Homes, op. cit., para.4.23.

115 ibid.

116 Op. cit.

117 Le Foe v Le Foe, op. cit., para.43.

118 "In my view what Lord Bridge of Harwich is saying is that the second class of case to which he is adverting, namely where there is no positive evidence of an express agreement between the parties as to how the equity is to be shared, and where the court has fallen back on inferring their common intention from the course of their conduct, it will only be exceptionally that conduct other than direct contributions to the purchase price, either in cash to the deposit or by contribution to the mortgage instalments, will suffice to draw the necessary inference of a common intention to share the equity."; ibid., per Mostyn J.

119 See n.4-6 and associated text.

120 Sharing Homes, op. cit., para.1.31(1).

121 See R. Probert, 'Trusts and the modern woman - establishing an interest in the family home' [2001]13 Child and Family Law Quarterly 275. 


\section{Northern Ireland Legal Quarterly [Vol. 56, No. 1]}

himself and his mistress - and with what can be regarded as 'easier cases'. In Oxley v Hiscock, the claimant had made substantial financial contributions; she had been advised by her solicitor to secure her position by joint ownership but had refused this advice; and by the time the dispute arose the mortgage had been paid off, both partners had secured alternative accommodation, the disputed property had been sold, and there were no other debts secured on the property. Ultimately, the effect of the Court of Appeal decision was to reduce Mrs Oxley's share from $50 \%$ to $40 \%$ of the proceeds of sale, on the basis that, presuming they had contributed equally to the mortgage, her financial contributions would have amounted to approximately $38 \%$.

Although Oxley v Hiscock could not be described as a 'hard case', the principles set out by the Court of Appeal will now, in the absence of an overruling judgment from the House of Lords, govern common intention constructive trusts pertaining to cohabitation. When 'harder' cases arise, as they inevitably will, the courts, and claimants, will welcome the greater degree of flexibility conferred by Chadwick LJ's 'fairness' criteria, which may help avoid the injustice that has often befallen non-legal title holders, particularly female partners, for whom a share of the property proportionate to their financial contribution does not amount to a fair result. Oxley v Hiscock provided a (relatively uncontroversial) opportunity for the Court of Appeal to consider the principles that should guide the courts in the future. It is unfortunate that the absence of a creditor enabled the court to avoid commenting on the implications of assimilating the constructive trust with proprietary estoppel on third parties. That, it must be presumed, is an issue which stands to be addressed in a 'hard case' in the future. 